\title{
Efficacy of Trunk Barriers for the Control of Key Pests on Trellised Grapevines
}

\author{
A. Schwartz \\ Submitted for publication: November 1987 \\ Accepted for publication: April 1988 \\ Keywords: Trunk barrier, snoutbeetle, ants, grapevines
}

Viticultural and Oenological Research Institute, Private Bag X5026, 7600 Stellenbosch, Republic of South Africa.

\begin{abstract}
Different trunk barriers were evaluated for the simultaneous control of snoutbeetles (Phlyctinus callosus Boh., Eremnus setulosus Boh.) and the Argentine ant Iridomyrmex humilis (Mayr.) on trellised grapevines. The polybutenebased sticky barriers Formex, Formex on Bidim and Plantex were effective in preventing snoutbeetles and ants from gaining access to the vegetative part of the vine. Phytotoxicity did not occur.
\end{abstract}

Ants and snoutbeetles are important pests of grapevines which require annual chemical control. Although the chemical approach provides satisfactory control of the mentioned pests, the disadvantages are well known. For this reason alternative methods of control are being sought.

The pests mentioned above are incapable of flight and can consequently only reach the vegetative parts of the vine by way of the trunk and trellis poles. An effective barrier preventing such access to the vegetative parts of the vines would therefore limit damage by these pests without the undesirable consequences of applying chemical pesticides. Thirty-three years ago a sticky band, Ostico, was already being used on the trunks of citrus trees for the control of ants (Steyn, 1954). Later Buitendag \& Holzhauzen (1970) recommended a polybutene-based material (Formex) as trunk band for ants on citrus. According to Samways \& Tate (1984) the direct application of Formex onto the trunks of citrus trees was phytotoxic to the bark. As a result different foundation layers were tested which led to the present recommendation of Formex in combination with geofabric (Bidim) and stretch-film plastic (Gladwrap) (Samways \& Tate, 1985).

In the light of the above-mentioned facts, it was considered necessary to investigate the potential of physical and chemical barriers for the control of snoutbeetles and ants on grapevines.

\section{MATERIALS AND METHODS}

Experiments were carried out in trellised vineyards at Robertson (cultivar Chenin blanc) during the 1983/ 84 and 1984/85 seasons, and at Stellenbosch (cultivar Cape Riesling) during the 1984/85 season. Two species of snoutbeetle were involved, i.e. Eremnus setulosus Boh. (Stellenbosch) and Phlyctinus callosus Boh. (Robertson), as well as the Argentine ant, Iridomyrmex humilis (Mayr.) which was found only in the vineyard at Stellenbosch.

The trial at Robertson during the 1983/84 season, consisted of the following treatments, viz. Formex on Bidim, Rever Ant, steelwool, tobacco dust, acephate and deltamethrin. Following the results obtained, some of the above treatments were excluded, and others added for the second season of testing (Table $1 \& 2$ ). Treatments included in the trial at Stellenbosch were the same as those for the Robertson trial during the
1984/85 season (Table $2 \& 3$ ).

Sticky barriers, approximately $20 \mathrm{~mm}$ wide x $5 \mathrm{~mm}$ thick of Formex, Rever Ant, Plantex and Fairlane Ant Barrier were applied to the trunks of vines at a height of 400-500 mm after the bark had been removed. Shellsper, steelwool $(30 \mathrm{~mm}$ wide), the foundation layer geofabric (onto which the sticky barrier Formex was applied) and sponge-rubber (a $30 \mathrm{~mm}$ wide band soaked in a standard acephate mixture) were tied around the trunk. Tobacco dust was spread by hand around the base of the trunk.

The treatments acephate, deltamethrin and tobacco dust (mixed with water to form a slurry) were applied directly to the trunk to a height of $400 \mathrm{~mm}$. The insecticides acephate and deltamethrin were sprayed onto the trunk at registered concentrations as for snoutbeelte control whereas the slurry was applied with a paint brush. Untreated control vines were part of each of the experiments.

Single plant plots, with six (Stellenbosch) and eight (Robertson) replications per treatment in a randomised block design, were treated during the middle of October. Measures were taken to prevent insect movement from untreated to treated vines by treating trellis poles and wires with Formex as well as by regular pruning of shoots. The rest of the vineyard was left untreated. Treatments were not repeated during a season.

The effectiveness of the trunk barriers was assessed at two weekly intervals from October to February or March. Snoutbeetles were monitored by means of cardboard strips placed above the trunk barrier according to Schwartz (1985). At Robertson only the results from two of the assessment dates during each of the two seasons, when the snoutbeetle population was at its highest, were subjected to a standard analysis of variance using $\log$ transformations. Next, an analysis of all the results for the total observation period for each season, was carried out.

A light infestation of E. setulosus occurred in the experimental plots at Stellenbosch. Consequently only the end result, i.e. the total figures obtained over the full observation period, was analysed.

As general ant activity commenced at the beginning of the year, only the results from the last four evaluations, between 06.02.1985 and 20.03.1985 were considered. The presence or absence of ants above the trunk barriers, i.e. between the latter and the crotch, was 
TABLE 1

Evaluation of trunk barriers for the control of the snoutbeetle Phlyctinus callosus on trellised grapevines, Robertson - 1983/84 season.

\begin{tabular}{|c|c|c|c|c|c|c|c|c|c|}
\hline \multirow{3}{*}{ Treatment } & \multicolumn{8}{|c|}{ Mean number of snoutbeetles in carton strips } & \multirow{3}{*}{$\begin{array}{c}\text { Total } \\
\text { (120 days) }\end{array}$} \\
\hline & \multicolumn{8}{|c|}{ DATE } & \\
\hline & $28-10-83$ & $14-11-83$ & $29-11-83$ & $09-12-83$ & $20-12-83$ & $16-01-84$ & 30-01-84 & $15-02-84$ & \\
\hline 1. Formex on Bidim (geofabric) & 0 & $1,2 \mathrm{a}^{*}$ & $1,1 \mathrm{a}$ & 0,8 & 0,1 & 0 & 0 & 0 & $0,4 \mathrm{a}$ \\
\hline 2. Rever Ant & 0 & $1,5 \mathrm{a}$ & $1,6 \mathrm{a}$ & 0,6 & 0,3 & 0 & 0,2 & 0 & $0,5 a$ \\
\hline 3. Steelwool & 1,2 & $96,2 b$ & $107,2 b$ & 21,7 & 2,3 & 2,0 & 3,7 & 2,0 & $29,5 b$ \\
\hline 4. Tobacco dust: trunk treatment & 1,1 & $43,7 \mathrm{~b}$ & $56,8 \mathrm{~b}$ & 17,1 & 1,5 & 1,0 & 2,3 & 2,1 & $24,4 \mathrm{~b}$ \\
\hline 6. Acephate: trunk treatment & 0,2 & $37,5 b$ & $34,6 b$ & 7,5 & 1,2 & 0,2 & 1,1 & 0,1 & $10,3 b$ \\
\hline 7. Deltamethrin: trunk treatment & 0,1 & $16,8 \mathrm{ab}$ & $18,0 \mathrm{a}$ & 8,2 & 1,1 & 0,3 & 0,5 & 2,0 & $5,6 \mathrm{ac}$ \\
\hline 8. Acephate in sponge rubber & 0,7 & $37,5 \mathrm{ab}$ & $29,7 b$ & 6,6 & 0,6 & 1,0 & 2,0 & 0,7 & $14,5 \mathrm{~b}$ \\
\hline 9. Untreated & 1,0 & $54,7 \mathrm{~b}$ & $42,5 b$ & 12,0 & 1,2 & 1,5 & 3,0 & 3,0 & $14,8 \mathrm{bc}$ \\
\hline
\end{tabular}

*Means followed by the same letter are not significantly different at $P \leqslant 0,05$.

noted as either positive or negative and converted to mean percentage uninfested plants for the above-mentioned period. The results were transferred to arcsine before an analysis of variance was carried out. Finally, a cut-off point of 90 percent uninfested plants was set for an acceptable treatment.

Any visual signs of phytotoxicity were checked for throughout the two-year period of testing.

\section{RESULTS AND DISCUSSION}

\section{Snoutbeetle}

Robertson ( $P$. callosus)

Results of the first season appear in Table 1. On 14.11.1983 and 29.11.1983 Formex on Bidim and Rever Ant afforded practical control of snoutbeetle and were significantly different from those of the untreated control. The insecticides acephate and deltamethrin which are registered and widely used as foliar sprays for the control of snoutbeetle, failed to provide protection as trunk treatments. This would seem to indicate that these chemicals do not react adequately as contact materials in the case of snoutbeetle. Other treatments that had poor reactions were tobacco dust and steelwool.

At the end of the trial period (overall) Formex on Bidim and Rever Ant remained significantly more effective than the untreated control (Table 1). However, the first four to six weeks of an infestation is critical as the young bunches are attacked during this period. Thus the need for extended control diminishes during the course of the season.
From the results of the second season (Table 2) it is evident that all the sticky barriers, i.e. Formex, Rever Ant, Formex on Bidim and Fairlane Ant Barrier as well as the Shell-sper were significantly more effective than the untreated control on 23.11.1984 and 07.12.1984. This same situation existed at the end of the trial for the total period.

\section{Stellenbosch (E. setulosus)}

The results appear in Table 3 . Notwithstanding the very light infestation which occurred in the test site, every one of the sticky barriers, i.e. Formex, Rever Ant, Plantex, Formex on Bidim and Fairlane Ant Barrier as well as Shell-sper were significantly more effective than the untreated control. This corresponds with the outcome of the 1984/85 Robertson trial.

\section{Ants}

Stellenbosch

The results are illustrated graphically in Fig. 1. All of the treatments, except Shell-sper, were significantly different from the untreated control. However, only three of the treatments, i.e. Formex, Formex on Bidim and Plantex conformed to the requirements with $100 \%$, $92 \%$ and $96 \%$ uninfested plants respectively after a period of 164 days

\section{Phytotoxicity}

During the two year period of testing on vines no form of phytotoxicity was observed. As a precaution

TABLE 2

Evaluation of trunk barriers for the control of the snoutbeetle Phlyctinus callosus on trellised grapevines, Robertson - 1984/85 season.

\begin{tabular}{|c|c|c|c|c|c|c|c|c|c|c|}
\hline \multirow{3}{*}{ Treatment } & \multicolumn{9}{|c|}{ Mean number of snoutbeetles in carton strips } & \multirow{3}{*}{$\begin{array}{c}\text { Total } \\
\text { (123 days) }\end{array}$} \\
\hline & \multicolumn{9}{|c|}{ DATE } & \\
\hline & $26-10-84$ & $08-11-84$ & 23-11-84 & $07-12-84$ & $20-12-84$ & 04-01-85 & $18-01-85$ & $01-02-85$ & $12-02-85$ & \\
\hline 1. Formex & 0 & 0 & $0,1 \mathrm{a}^{*}$ & $0,0 \mathrm{a}$ & 0 & 0 & 0,1 & 0 & 0 & $0,2 \mathrm{a}$ \\
\hline 2. Rever Ant & 0 & 0 & $0,3 a$ & $0,2 \mathrm{a}$ & 0,2 & 0 & 0,3 & 0 & 0 & $1,1 \mathrm{a}$ \\
\hline 3. Plantex & 0 & 0 & $0,0 \mathrm{a}$ & $0,4 \mathrm{a}$ & 0 & 0 & 0 & 0 & 0,1 & $0,5 \mathrm{a}$ \\
\hline 4. Formex on Bidim (geofabric) & 0 & 0,2 & $0,0 \mathrm{a}$ & $0,0 \mathrm{a}$ & 0 & 0 & 0 & 0 & 0 & $0,2 \mathrm{a}$ \\
\hline 5. Fairlane Ant Barrier & 0 & 0 & $0,4 a$ & $0,9 \mathrm{a}$ & 0 & 0 & 0,1 & 0 & 0 & $1,5 \mathrm{a}$ \\
\hline 6. Shell-sper & 0 & 1,3 & $19,8 \mathrm{~b}$ & $7,5 \mathrm{~b}$ & 1,2 & 1,5 & 2,5 & 1,1 & 1,7 & $38,7 \mathrm{~b}$ \\
\hline 7. Untreated & 0,1 & 3,7 & $55,5 \mathrm{c}$ & $29,0 \mathrm{c}$ & 5,5 & 2,5 & 4,3 & 4,5 & 5,5 & $118,0 \mathrm{c}$ \\
\hline
\end{tabular}

*Means followed by the same letter are not significantly different at $P \leqslant 0,05$. 
TABLE 3

Evaluation of trunk barriers for the control of the snoutbeetle Eremnus setulosus, on trellised grapevines, Nietvoorbij, Stellenbosch.

\begin{tabular}{|l|l|}
\hline Treatment & $\begin{array}{l}\text { Number of snoutbeetles } \\
\text { in carton strips during } \\
09-11-84 \text { to 20-03-85 } \\
\text { (thirteen assessments; } \\
164 \text { days) }\end{array}$ \\
\hline 1. Formex & $0,1 \mathrm{a}^{*}$ \\
2. Formex on Bidim & \\
(geofabric) & $0,0 \mathrm{a}$ \\
3. Plantex & $0,0 \mathrm{a}$ \\
4. Rever Ant & $0,2 \mathrm{a}$ \\
5. Fairlane Ant Barrier & $0,1 \mathrm{a}$ \\
6. Shell-sper & $0,5 \mathrm{a}$ \\
7. Untreated & $3,6 \mathrm{~b}$ \\
\hline
\end{tabular}

* Means followed by the same letter are not significantly different at $\mathrm{P} \leqslant 0,05$.

against possible phytotoxicity, a foundation layer (Bidim) was tested in conjunction with Formex. Although this barrier functioned well, the Bidim is cost additive. Moreover, it is not completely antproof as it allows gaps under the band where indentations are found on the trunk of the vine and therefore has to be attached with care.

\section{CONCLUSIONS}

Each of the sticky trunk barriers tested provided excellent control of the two snoutbeetle species, both with regard to short- and long term. These are Formex, Formex on Bidim, Plantex, Fairlane Ant Barrier and Rev- er Ant. Shell-sper, however, was inferior to the aforementioned. The registered insecticides acephate and deltamethrin, which were applied as trunk treatments, were unsatisfactory.

Practical control of the Argentine ant, I. humilis, was achieved for the duration of the season with the sticky barriers, Formex, Plantex and Formex on Bidim.

The aim of the investigation was achieved by successfully testing a dual purpose trunk barrier. Thus where snoutbeetles and ants are abundant and troublesome, which in fact is a common phenomenon in vineyards of the Western Cape, the sticky barriers Formex or Plantex will suffice. Utilizing such a trunk barrier could have far-reaching implications, viz. a reduction in toxic chemical sprays for pests would mean a lessening of the chances of pollution of the environment and improvement of biological control of important pests such as vine mealy bug, Planococcus ficus (Signoret), and common red spider, Tetranychus urticae Koch. This should lead to a saving in spray costs.

\section{LITERATURE CITED}

BUITENDAG, C.H. \& HOLTZHAUZEN, L.C., 1970. 'n Nuwe taai mierversperring vir sitrusbome. S. Afr. Citrus J. no. 444 7-9.

SAMWAYS, M.J. \& TATE, B.A., 1984. Evaluation of several trunk barriers used to prevent the movement of the pugnacious ant [(Anoplolepis custodiens (Smith)] into citrus trees. Citrus and Subtropical Fruit Journal 608, 9,10,11,12,20,23,25,26

SAMWAYS, M.J. \& TATE, B.A., 1985. A highly efficacious and inexpensive trunk barrier to prevent ants from entering citrus trees. Citrus and Subtropical Fruit Journal 610, 12, 13, 18.

STEYN, J.J., 1954. The pugnacious ant [(A. custodiens (Smith)] and its relation to the control of citrus scales at Letaba. Mem. ent Soc. sth. Afr. no. 3, 1-96.

SCHWARTZ, A., 1985. The seasonal occurrence of the snoutbeetle, Phlyctinus callosus Boheman (Coleoptera : Curculionidae) on Vines in the Robertson area. S. Afr. J. Enol. Vitic. 6, 21-22.

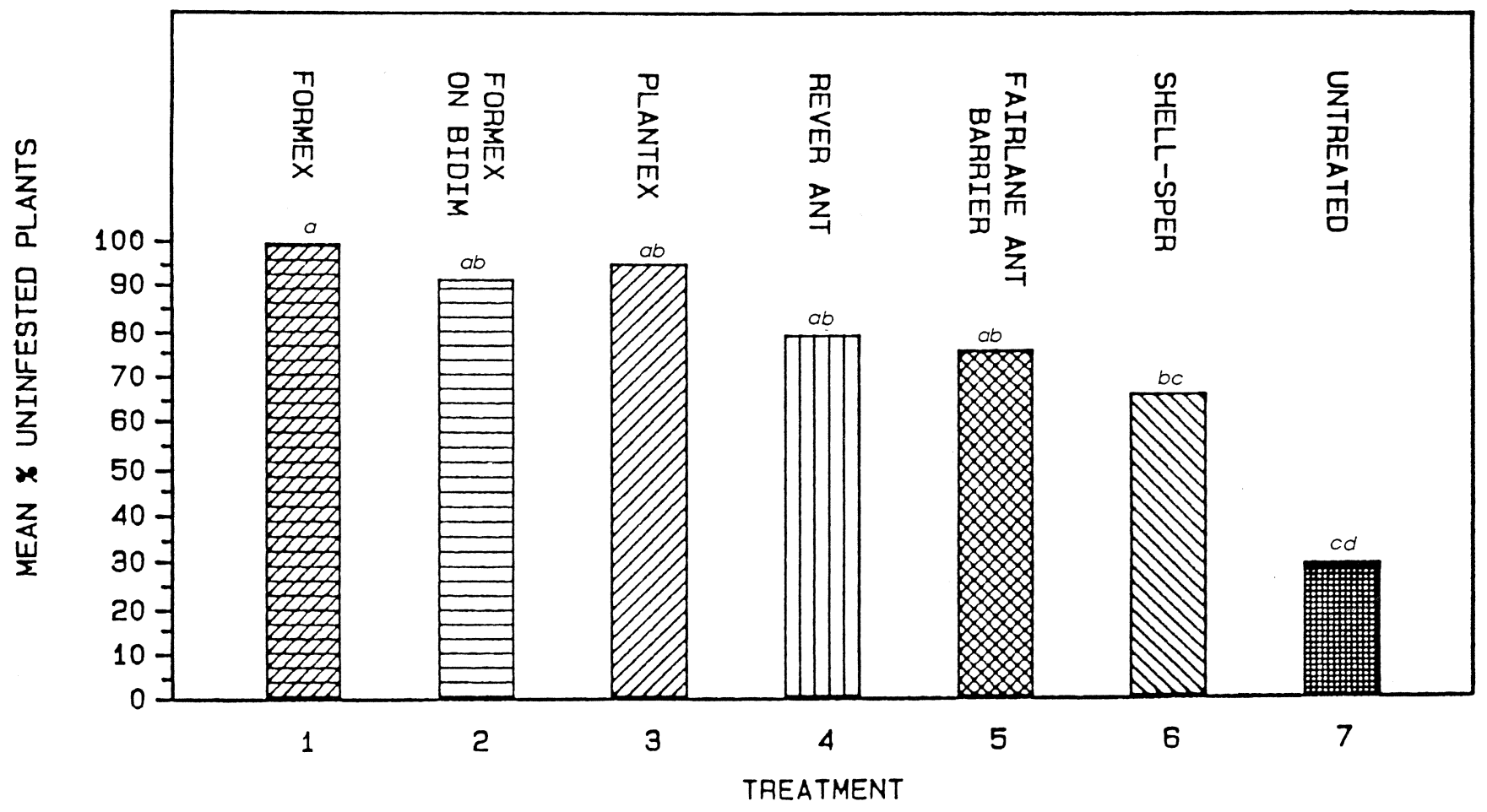

FIG. 1

The effectiveness of trunk barriers for the control of I. humilis on vines (treatment numbers correspond to those given in Table 3 . Treatments with the same letter are not significantly different at $P \leqslant 0,05$. 